\title{
Covid-19: When the Misinformation Is Spreading Faster Than the Virus
}

\author{
Joshua Chadwick Jayaraj ${ }^{1 *}$, Divya Mahalingam ${ }^{1}$, Geevaprabhakaran Ganesan ${ }^{2}$ \\ ${ }^{1}$ Nalatham Charitable Trust Clinic, Chennai, India \\ ${ }^{2}$ Vasuganesan Family clinic, Chennai, India
}

*Corresponding author: Joshua Chadwick Jayaraj, Nalatham Charitable Trust Clinic, Chennai, India.

Received date: May 15, 2020; Accepted date: May 29, 2020; Published date: June 15, 2020

Citation: Joshua Chadwick Jayaraj, Divya Mahalingam, Geevaprabhakaran Ganesan, (2020) Covid-19: When The Misinformation Is Spreading Faster Than The Virus. J Thoracic Disease and Cardiothoracic Surgery, 1(1); DOI:10.31579/2693-2156/005

Copyright: (C) 2020 Joshua Chadwick Jayaraj, This is an open access article distributed under the Creative Commons Attribution License, which permits unrestricted use, distribution, and reproduction in any medium, provided the original work is properly cited.

Globally, as on March 17, 2020, 179111 confirmed cases along with 7426 deaths have been reported [1]. One of the World Health Organization's (WHO) strategic objectives for this response is to communicate critical risk and event information to all and counter misinformation. We, therefore, aimed to highlight the key information issued by the WHO on preventive measures.

Human-to-human transmissions have been described with incubation period between 2-10 days, facilitating its spread via droplets, contaminated hands or surfaces. In many instances, COVID-19 infection will cause mild respiratory illness including a runny nose, sore throat, fever, and cough, however, it can cause severe illness and, in some people, it can be fatal especially in elderly, and those with pre-existing medical conditions such as cardiovascular disease, chronic respiratory disease, hypertension or diabetes. The re-estimated mortality rate for China is 5.6 $\%$ and $15.2 \%$ elsewhere [2].

Wash your hands frequently with soap and water or use an alcohol-based hand rub if your hands are not visibly dirty [1]. When coughing and sneezing, cover mouth and nose with flexed elbow or tissue - discard tissue immediately into a closed bin and clean your hands with alcoholbased hand rub or soap and water. Hands touch many surfaces which can be contaminated with the virus. If you touch your eyes, nose or mouth with your contaminated hands, you can transfer the virus from the surface to yourself.

Maintain at least 1 metre ( 3 feet) distance between yourself and other people, particularly those who are coughing, sneezing and have a fever. Wearing a medical mask can help limit the spread of some respiratory disease. However, using a mask alone is not guaranteed to stop infections and should be combined with other prevention measures including hand and respiratory hygiene and avoiding close contact.

According to $\mathrm{WHO}$, the consumption of raw or undercooked animal products should be avoided. Raw meat, milk or animal organs should be handled with care, to avoid cross-contamination with uncooked foods, as per good food safety practices. People receiving packages are not at risk of contracting the COVID-19. From experience with other coronaviruses, it is has been identified that these types of viruses don't survive long on objects, such as letters or packages although it can survive. A recent study identifies that human coranviruses can persist on inanimate surfaces like metal, glass or plastic for up to 9 days, but can be efficiently inactivated by surface disinfection procedures with $62-71 \%$ ethanol, $0.5 \%$ hydrogen peroxide or $0.1 \%$ sodium hypochlorite within 1 minute [3].

So far the evidence suggests that the COVID-19 virus can be transmitted in all climate, including areas with hot and humid weather [4]. Hitherto, no specific therapies are available for COVID-19, rapid dissemination of verified information is the most effective prevention against the disease of misinformation.

\section{References}

1. https://www.who.int/docs/defaultsource/coronaviruse/situation-reports/20200317-sitrep-57covid-19.pdf?sfvrsn=a26922f2_4. https://www.who.int/docs/defaultsource/coronaviruse/situation-reports/20200317-sitrep-57covid-19.pdf?sfvrsn=a26922f2_4. Accessed March 19, 2020.

2. Baud D, Qi X, Nielsen-Saines K, Musso D, Pomar L, Favre G. Real estimates of mortality following COVID-19 infection. Lancet Infect Dis. 2020;0(0).

3. Kampf G, Todt D, Pfaender S, Steinmann E. Persistence of coronaviruses on inanimate surfaces and their inactivation with biocidal agents. J Hosp Infect. 2020;104(3):246-251.

4. Myth busters. https://www.who.int/emergencies/diseases/novelcoronavirus-2019/advice-for-public/myth-busters. Accessed March 19, 2020. 
